\author{
О. Олькіна, \\ кандидат юридичних наук, доцент, \\ доцент кафедри конституційного права \\ Національного університету «Одеська юридична академія»
}

\title{
ЧЕТВЕРТИЙ ВСЕУКРАЇНСЬКИЙ КОНКУРС НАУКОВИХ РОБІТ ІМЕНІ М. П. ОРЗІХА «ЛЮДСЬКИЙ ВИМІР ПРАВА»
}

8 листопада 2019 року у Національному університеті «Одеська юридична академія» відбувся Четвертий Всеукраїнський конкурс наукових робіт «Людський вимір права» (далі - Конкурс), присвячений вшануванню пам'яті Марка Пилиповича Орзіха, видатного вченого-конституціоналіста, Академіка Академії правових наук України, Украінської академії політичних наук, Української муніципальної академії, доктора юридичних наук, професора, заслуженого діяча науки і техніки України, автора-виконувача, експерта щодо проектів Конституцій СРСР та УРСР (1977р., 1978 р.), Конституції України (1996 р.).

Організаторами конкурсу виступили рідні та учні Марка Пилиповича, а також натхненні його життєвим прикладом учасники студентського дискусійного клубу публічного права, колектив кафедри конституційного права, керівництво судово-адміністративного факультету Національного університету «Одеська юридична академія».

Унікальність Конкурсу обумовлена його метою виявити обдарованих студентів, сприяти активізації науково-дослідної роботи; стимулювати до творчого самовдосконалення, а також захисту прав людини в Україні. Переможець Конкурсу отримує грошову премію ім. М.П. Орзіха та можливість опублікувати наукову статтю у науково-практичному фаховому журналі «Юридичний вісник».

На урочистому відкритті Конкурсу проректор з наукової роботи Національного університету «Одеська юридична академія», доктор юридичних наук, професор М.Р. Аракелян розповів про науковий внесок М. П. Орзіха у розвиток вітчизняної науки, його теоретичні та методологічні здобутки, створену ним наукову школу людського виміру права.

Сам Конкурс проводився у два етапи. За результатами першого етапу конкурсною комісією було відібрано шість найкращих письмових робіт, а їх авторів було запрошено до Національного університету «Одеська юридична академія» для здійснення прилюдного захисту та презентації ключових ідей їх наукових праць.

Конкурсна програма складалась з таких доповідей:

1. Шрамова Олександра, аспірантка 3-го року навчання юридичного факультету Київського національного університету ім. Тараса Шевченка (м. Київ) у доповіді «Справа про початок людського життя» стверджує, що у випадку переривання вагітності на строках пізніше 22-х тижнів, дитина може вижити, однак передчасне народження може мати негативні наслідки для здоров'я дитини у вигляді ризику розвитку короткострокових та довгострокових захворювань, таких як дитячий церебральний параліч, розумові розлади, хронічне запалювання легенів, втрата слуху і зору тощо. Окрім того, передчасне народження може мати наслідком смерть дитини, як це сталося у справі, розглянутій Овідіопольським районним судом. Тілесне ушкодження може бути не лише умисним, але і необереж- 


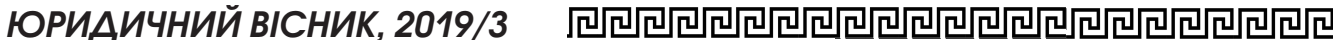

ним, воно також може не призвести до переривання вагітності, однак все одно завдати шкоди дитині на пренатальній стадії розвитку. У зв'язку з цим, вона пропонує доповнити Кримінальний кодекс України статтями 128-1. Необережне тілесне ушкодження, заподіяне дитині, що знаходиться на пренатальній стадії розвитку та 125-1. Умисне тілесне ушкодження дитині, що знаходиться на пренатальній стадії розвитку.

2. Шкільнюк Анастасія, студентка 1-го курсу магістратури соціально-правового факультету Національного університету «Одеська юридична академія» (м. Одеса)

у доповіді «Право на повагу до особистого та сімейного життя vs діяльність 3MI» наголошує, що захист права на таємницю приватного та сімейного життя публічних службовців потребує додаткового захисту, оскільки останнім часом популярною стає тенденція охорони та захисту інтересів громадян України, які не перебувають на публічній службі. Такий напрямок політики держави зумовлює процедурну та процесуальну незахищеність осіб, які більшою мірою виконують обов'язки держави. Зокрема, антикорупційна політика України достатньою мірою робить «відкритим» приватне життя осіб, на яких покладаються обов'язки держави, прикладом цього факту $є$ «е-декларування» не лише самих публічних службовців, а також їхніх членів сім”і.

Вважає за доцільне встановити відповідальність для керівників прес-центрів, видавництв, інших осередків журналістської діяльності, а особливо звернути увагу на можливість відповідальності за розповсюдження матеріалів, що містять ознаки порушення права на повагу до особистого та сімейного життя, у мережі Інтернет.

3. Подоляка Тетяна, студентка 4-го курсу факультету правничих наук Національного університету «Києво-Могилянська академія» (м. Київ) у доповіді «Право на соціальний захист військовослужбовців у рішеннях Конституційного Суду України» зауважує, що необ- хідність створення ефективної системи соціального захисту військовослужбовців $є$ очевидною, адже, по-перше, така система сприятиме поповненню української армії новими кадрами, буде більше мотивації служити в армії за умов ефективного забезпечення соціального захисту, по-друге, це важливий спосіб забезпечення основоположних прав людини та недопущення їх порушення. Конституційний Суд України у своїх рішеннях сприяє визначенню меж та обсягу соціального захисту, сприяє ліквідації прогалин, дотриманню «духу» Конституції. Конституційна скарга є тим інститутом, що наближує Суд до військовослужбовців, демонструє нагальні проблеми, але цей інститут перебуває на етапі становлення та все ще потребує реформування.

4. Наконечна Анна, асистент кафедри теорії та філософії права юридичного факультету Львівського національного університету ім. Івана Франка (м. Львів) у доповіді «Зумовленість людськими потребами та інтересами правозастосовчої і правотлумачної діяльності» дійшла висновків, що за сферою життєдіяльності найчастіше згадуються особистісні (20 випадків) та політичні (20 випадків) потреби й інтереси, порівняно 3 економічними (8 випадків). Згадки ж про потреби й інтереси у сфері соціального захисту та культурно-духовні у постановах Верховного суду України та рішеннях Конституційного Суду України за досліджуваний період (2015-2017рр.) взагалі не виявлені. За суб'єктом-носієм найпоширенішими є згадки про потреби й інтереси індивідуально-колективні (20 випадків), на відміну від суто індивідуальних (18) та колективних (16 випадків). Це можна пояснити тим, що вони порівняно 3 виключно колективними та індивідуальними завжди пов'язані із конкретною ситуацією, яка, зазвичай, i $€$ предметом регулювання правозастосовчих судових рішень.

5. Миславський Інокентій, студент 4-го курсу Інституту підготовки кадрів для органів юстиції України Національного юридичного універси-

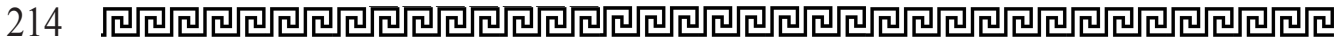


тету ім. Ярослава Мудрого (м. Харків) у доповіді «До питання використання практики Європейського суду $з$ прав людини в контексті забезпечення юридичного антропоцентризму та захисту основоположних прав особи в мережі інтернет» зауважує, що в межах глобальної мережі Інтернет людина може реалізувати ряд основоположних прав, серед яких свобода вираження поглядів, право на доступ до інформації, право на поширення інформації, право на захист персональних даних та таємницю приватного життя, право на захист честі та гідності тощо. Особливої уваги потребує проблематика захисту прав та інтересів дітей в мережі Інтернет. ЄСПЛ виділяє багато проблем юридичного закріплення та захисту i забезпечення цифрових прав. Проте, всі вони зводяться о того, що цифрові права вже давно перестали мати похідний характер і перетворилися на самостійну юридичну категорію, який потребує власного регламентування, яке більша частина держав не здатна надати через розрив між темпами розвитку права та інформаційних систем відповідно. В залежності від ситуації, ЄСПЛ може по-різному тлумачити як сутність глобальної мережі Інтернет та інформаційних прав людини, так і визначати наявність або відсутність їхнього порушення. В Україні існують проблеми із застосуванням Рішень ЄСПЛ в якості джерела права при регулюванні суспільних відносин в мережі Інтернет. Для вирішення цієї проблеми перспективним стане продовження наукових досліджень у двох напрямках: щодо поглиблення регулювання окремих видів цифрових прав людини з точки зору висновків ЄСПЛ, та стосовно винайдення практично придатних механізмів перекладення цього європейського досвіду в український правовий контекст.

6. Андреєв Тит, студент 1-го курсу магістратури господарсько-правового факультету Національного юридичного університету ім. Ярослава Мудрого (м. Харків) у доповіді «Людина в обширі українського права: нарис до інституційно-антропологічного розуміння» зазначив, що Україна поки знаходиться на периферії західноєвропейського ціннісно-правового виміру, не до кінця розвинулася в модерну державу, таку, як їі розглядати Макс Вебер, інші та у протистоянні \співпраці інституційності та персональної важливості у суспільно-важливих правово-політичних зв'язках поки що виграє остання, що спричинює постійну зміну реальної компетенції при збереженні формальної, необгрунтовано сильну роль окремих урядовців і занадто слабку інших, зокрема судової влади та органу конституційної юрисдикції, що стають маніпулятивним інструментом в руках інших гілок, повільний процес імплементації реформ, що наштовхуються на сильний спротив з боку регіональної та місцевої влади. Цілком можливо, що такий сильний особистісний зв'язок певним чином впливає на рівень корупції в державному апараті та спричиняє його надмірну жорсткість до змін, нездатність вирішувати ординарні та передбачені законодавством повноваження.

Обрання переможця Конкурсу було складним завданням для конкурсної комісії, до складу якої входили М.Р. Аракелян, М.В. Афанасьєва, Ю.Д. Батан, В.С. Віткова, А.А. Єзеров, Ю.Г. Орзіх та О.В. Олькіна. Оцінювання виступів здійснювалось за п'яти бальною шкалою по таким критеріям як актуальність, досягнення мети роботи, оригінальність та самостійність дослідження, доступність викладення матеріалу, обгрунтування висновків роботи та їх практичне значення, ораторське мистецтво, якість та творчий характер презентації, відповіді на запитання, дотримання регламенту доповіді.

У результаті підбиття підсумків було визначено переможця Конкурсу, яким став Миславський Інокентій, студент 4-го курсу Інституту підготовки кадрів для органів юстиції України Національного юридичного університету ім. Ярослава Мудрого. 